\title{
Distributed education enables distributed economic impact: the economic contribution of the Northern Ontario School of Medicine to communities in Canada
}

\author{
John C. Hogenbirk ${ }^{1 *}$ (D), David R. Robinson ${ }^{2}$ and Roger P. Strasser ${ }^{3}$
}

\begin{abstract}
Background: Medical schools with distributed or regional programs encourage people to live, work, and learn in communities that may be economically challenged. Local spending by the program, staff, teachers, and students has a local economic impact. Although the economic impact of DME has been estimated for nations and subnational regions, the community-specific impact is often unknown. Communities that contribute to the success of DME have an interest in knowing the local economic impact of this participation. To provide this information, we estimated the economic impact of the Northern Ontario School of Medicine (NOSM) on selected communities in the historically medically underserviced and economically disadvantaged Northern Ontario region.

Methods: Economic impact was estimated by a cash-flow local economic model. Detailed data on program and learner spending were obtained for Northern Ontario communities. We included spending on NOSM's distributed education and research programs, medical residents' salary program, the clinical teachers' reimbursement program, and spending by learners. Economic impact was estimated from total spending in the community adjusted by an economic multiplier based on community population size, industry diversity, and propensity to spend locally. Community employment impact was also estimated.

Results: In 2019, direct program and learner spending in Northern Ontario totalled $\$ 64.6 \mathrm{M}$ (million) Canadian Dollars. Approximately $76 \%$ (\$49.1 M) was spent in the two largest population centres of 122,000 and 165,000 people, with 1-5\% (\$0.7 M - \$3.1 M) spent in communities of 5000-78,000 people. In 2019, total economic impact in Northern Ontario was estimated to be $\$ 107 \mathrm{M}$, with an impact of $\$ 38 \mathrm{M}$ and $\$ 36 \mathrm{M}$ in the two largest population centres. The remaining $\$ 34 \mathrm{M}(32 \%)$ of the economic impact occurred in smaller communities or within the region. Expressed alternatively as employment impact, the 404 full time equivalent (FTE) positions supported an additional 298 FTE positions in Northern Ontario. NOSM-trained physicians practising in the region added an economic impact of $\$ 88 \mathrm{M}$.
\end{abstract}

\footnotetext{
* Correspondence: jhogenbirk@laurentian.ca

'Centre for Rural and Northern Health Research, Laurentian University, 935

Ramsey Lake Road, Greater Sudbury, Ontario P3E 2C6, Canada

Full list of author information is available at the end of the article
}

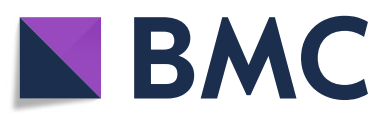

(- The Author(s). 2021 Open Access This article is licensed under a Creative Commons Attribution 4.0 International License, which permits use, sharing, adaptation, distribution and reproduction in any medium or format, as long as you give appropriate credit to the original author(s) and the source, provide a link to the Creative Commons licence, and indicate if changes were made. The images or other third party material in this article are included in the article's Creative Commons licence, unless indicated otherwise in a credit line to the material. If material is not included in the article's Creative Commons licence and your intended use is not permitted by statutory regulation or exceeds the permitted use, you will need to obtain permission directly from the copyright holder. To view a copy of this licence, visit http://creativecommons.org/licenses/by/4.0/ The Creative Commons Public Domain Dedication waiver (http://creativecommons.org/publicdomain/zero/1.0/) applies to the data made available in this article, unless otherwise stated in a credit line to the data. 
Conclusions: By establishing programs and bringing people to Northern Ontario communities, NOSM added local spending and knowledge-based economic activity to a predominantly resource-based economy. In an economically deprived region, distributed medical education enabled distributed economic impact.

Keywords: Distributed medical education, Economic impact, Economic contribution, Socio-economic deprivation, Social accountability, Underserviced areas, Ontario, Canada

\section{Background}

In 2013, medical schools and teaching hospitals had an economic impact in Canada of $\$ 66 \mathrm{~B}$ (billion) $\mathrm{CDN}$ (Canadian Dollars) [1]. For distributed medical education (DME) programs, in which academic and clinical programs are offered in communities located away from the main campus, the economic impact is also distributed among participating communities and within the broader region $[2,3]$. DME program spending represents new money coming into rural or remote areas, and can help in the economic sustainability of these regions with the potential for improvements in the social determinants of health and health equity, which in turn can have positive economic impact [4-11]. However, with a few exceptions [2, 3], studies typically have been conducted at the level of the province, state, or nation, and while some studies may estimate the impact on capital cities or large regions, the economic impact is not estimated for the smaller cities or towns. Communities have an interest in knowing the community-specific economic impact, given the role of these communities in ensuring the success of DME. Our study sought to fill this information gap to estimate the economic impact of the Northern Ontario School of Medicine's (NOSM) fully operational community engaged health professional education and research programs for specific communities in the historically underserved and economically disadvantaged region of Northern Ontario.

NOSM's service region in Northern Ontario has 90\% of Ontario's land area (806,787 of 908,699 $\mathrm{km}^{2}$ ) —an area that exceeds that of the United Kingdom and France (exclusive of overseas territories) - but has only 6\% of the population of the province $(840,739$ of $13,448,494$ people) (Fig. 1) [12]. Communities in the lower part of the service region are connected by road, rail, and air, whereas those communities in the upper part are connected by air and winter (ice) roads. The economy of this region is largely resource based [13], with socioeconomic characteristics and population health statuses that are worse than the rest of the province [14]. NOSM's service region, relative to the whole province, has a higher proportion of Indigenous (14\% vs. $2 \%)$ and Francophone (24\% vs. $5 \%$ ) people [15-17]. These minority groups have comparatively lower socio-economic status, poorer health status, and worse access to healthcare services $[18,19]$.
The political decision to locate a stand-alone medical school in Northern Ontario rather than to exploit perceived scale efficiencies of established and larger medical schools in southern Ontario was undertaken to improve overall health outcomes and to counter the high cost of moving patients from remote communities to doctors in the major cities. Previous initiatives aimed at improving access to healthcare services in Northern Ontario were not fully successful [20-22]. NOSM, which started accepting students in 2005, was established with an explicit social accountability mandate to help improve the health of the people of Northern Ontario [23, 24]. The deliberate creation of a new medical school in a historically underserved region sought to leverage the strong positive association between physicians' practice location and where they spent their childhood [25], as well as the strong positive association between practice location and where physicians completed their medical school education or residency training [22, 26-28]. These training opportunities were extended by NOSM to other healthcare practitioners such as dietitians and rehabilitation therapists. The establishment of NOSM as a distributed medical school was viewed as part of "comprehensive, four-year plan to invest in health and education, foster economic growth and balance the budget" in Northern Ontario [29].

At present, NOSM provides a distributed educational experience in over 90 communities for a broad range of students including undergraduate medical students, postgraduate medical residents, as well as dietetic, rehabilitation therapy, physician assistant, and pharmacy students [24]. In addition, students and graduate students from other health care professional schools undertake placements in the region. These programs, staff, learners, and teachers increase the economic activity in participating communities and surrounding lands. This study sought to estimate the community-specific economic impact of spending attributable to NOSM's education and research programs and related activities.

\section{Methods}

To estimate the economic impact, we built a cash-flow model using Excel (Microsoft Office Professional Plus 2013, v15.0.5153.1000) for communities clustered in eight economic zones (defined below) and for NOSM's service region in Northern Ontario in total. To this 


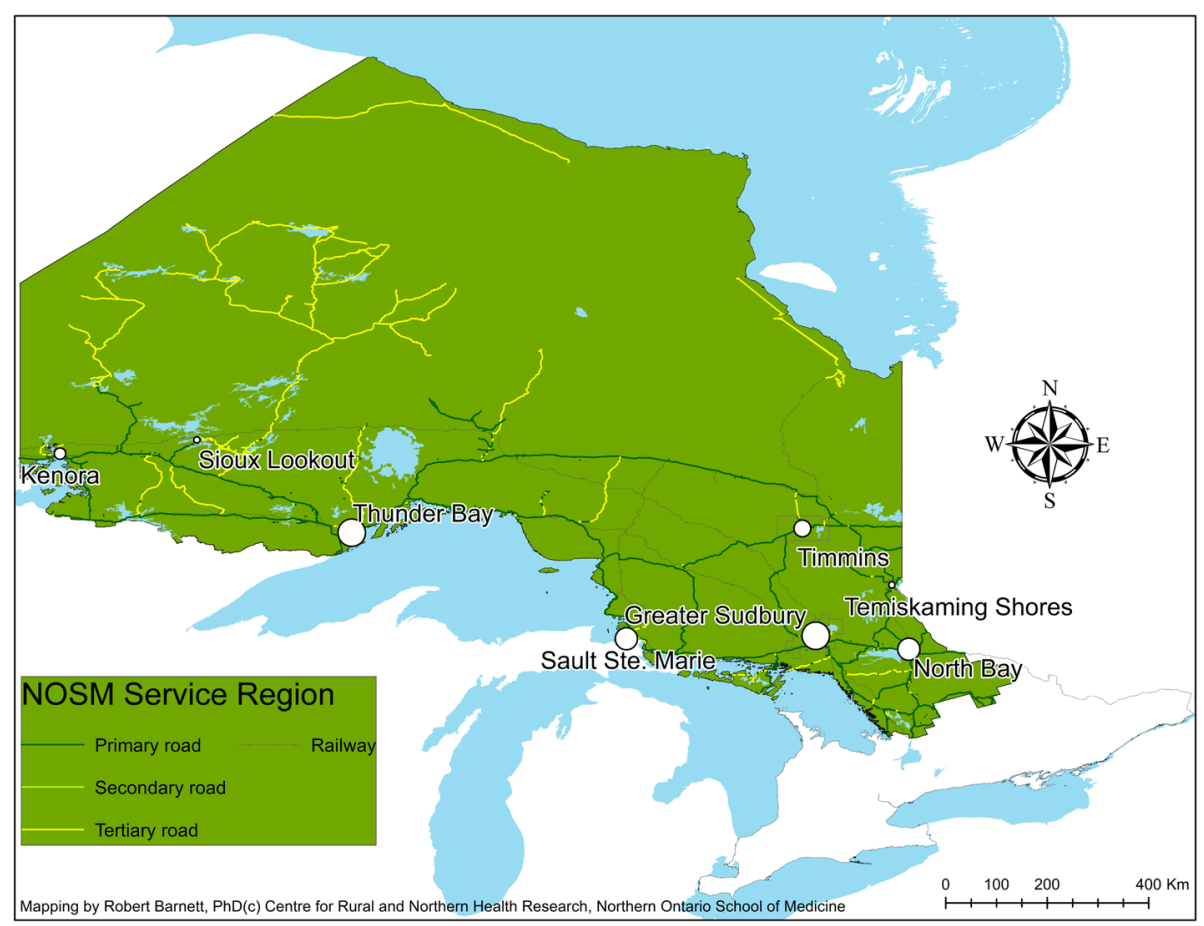

Fig. 1 Map showing major communities and transportation network in the service region of the Northern Ontario School of Medicine

accounting structure we added a local economic model [30-34] using multipliers that incorporated population size, industry diversity, and the propensity to spend locally-these multipliers were derived from a regression equation developed with data specific to Ontario communities [35, 36].

The eight distinct economic zones included two census metropolitan areas (CMAs, core population $\geq 100$, 000), four census agglomerations (CAs, core population $\geq 10,000$ ), and two of the larger census subdivisions (CSDs). CMAs and CAs include cities and surrounding lands that represent zones of integrated economic activity as inferred from commuter flows to urban cores [37]. One CSD had been part of a CA in 2001 and 2011 and therefore we grouped spending in all communities that had been part of the former CA, labelling this as Temiskaming Shores CSD+ (CSD plus). The second CSD of Sioux Lookout is a health and social service hub for 29 First Nation (Indigenous) communities distributed across northwest Ontario. NOSM-related spending (described below) in this community was high relative to population size. All other CSDs in the region with NOSM-related spending, including First Nations Indigenous communities, were grouped together to maintain confidentiality. We estimated the economic impact for this group as a whole using a multiplier based on average population size of 3260 people. We also estimated an additional intra-regional economic impact given that community members were known to purchase goods and services from other communities in the region.

Community-specific data that were used to develop the cash-flow model included: salaries and benefits of NOSM personnel and medical residents, and reimbursement for clinical teaching duties; spending on travel, supplies, and services; stipends paid to contract faculty; spending on educational programs; spending on research; and other spending for fiscal year (FY) 2014/ 2015. These totals include spending recorded through the Paymaster program for salaries of medical residents (one of several learner groups) and the academic Alternate Funding Plan for clinical teachers (Supplement 1). We estimated average local spending per week for all other learners. This average weekly spending was multiplied by the number of learner-weeks per community to estimate annual local spending. We refer to the combined spending on all programs and by all learners as NOSM-related spending. Full postal codes were used to locate the employee, resident, clinical teacher, or vendor in specific communities within NOSM's service region (Fig. 1).

Cash flow totals were cross-checked against publicly reported values in NOSM's Financial Statement of Operations [38], with "Amortization" replaced by "Cash flows from financing and investing activities (Obligations and Acquired)" plus payments to residents and clinical teachers. The cash flow model was constructed to best 
represent actual program, employee, teacher, and learner spending in Northern Ontario communities [39].

Data, particularly spending data, on programs that pre-dated NOSM were not readily obtainable and therefore the counterfactual was the absence of all programs in the service region, reflecting the "gross change in a region's existing economy that can be attributed to a given industry" [33]. Prior to NOSM, there were no medical school satellite or regional sites in Northern Ontario. Instead, there was a diverse collection of programs affiliated with other Ontario medical schools (Supplement 2). In 2005, NOSM started a new, full 4-year undergraduate medical education program and since then has added five more postgraduate medical specialties; plus physician's assistant and medical physics programs, and pharmacy placements. In 2005 to 2006, NOSM began consolidation of existing healthcare and medical education programs and has steadily increased enrolment, offered more types of placements, and recruited more healthcare providers, care facilities, and communities into its programs.

The economic model summed direct, indirect, and induced economic effects to estimate the total economic impact of these programs and people in the eight economic zones and for the whole of the service region. The community-specific multipliers combined all effects into a single estimate of economic impact. We used 2016 Canadian census population sizes [12] to calculate the multipliers (described above) that were applied to cash flows to estimate the impact of all monies that were available to be re-spent in the community or region, corrected for monies that leave Northern Ontario.

Detailed spending from FY 2014/2015 was made available to the research team. These spending data were multiplied by the ratio of total spending in FY 2018/ 2019 divided by total spending in FY 2014/2015 to estimate spending in FY 2018/2019. We checked the assumption that spending patterns were reasonably consistent from year to year by using a Chi-squared test of the count of dollars in each of the 15 major spending categories across five fiscal years. Community-specific multipliers were applied to the adjusted spending. The regional impact was estimated using a multiplier that was $10 \%$ higher than the largest community's multiplier, which seemed reasonable given intra-regional spending. The regional multiplier was applied to total adjusted spending in the region.

We calculated the effect on employment in Northern Ontario to obtain an alternative measure of the economic impact. The number of full time equivalent (FTE) positions included NOSM employees and faculty, as well as employees of health care facilities whose salary and benefits were paid in whole or in part by NOSM, but who were not formally NOSM employees. FTE data also included residents who were also not formally NOSM employees. Data on clinical teachers FTE were not readily available and could not be included. We increased the income multipliers by $4.1 \%$ before estimating FTE. This increase was based upon a comparison of income and employment multipliers estimated for census divisions in Northern Ontario [40].

We also calculated a first approximation of the economic impact of NOSM-trained physicians who located their practice in the service region. We used the number of physicians known to be practicing in the service region in November 2018, multiplied by average gross income for family physicians (FPs) in Ontario $(\$ 291,090)$, and adjusted by a published multiplier of 1.07 for family practices in Canada [28, 41, 42]. A regional impact was estimated using a multiplier that was $10 \%$ higher, and was applied to total gross income for the region. For simplicity, we assumed that average FP income also applied to other medical and surgical specialists.

\section{Results}

Adjusted financial statements showed that total spending by NOSM, including salary for medical residents and reimbursement for clinical teaching duties, increased from $\$ 37.5 \mathrm{M}$ in FY $2014 / 2015$ to $\$ 75.6 \mathrm{M}$ in FY 2018/2019. The amounts, counted in the hundreds of thousands of dollars, were not statistically significantly different among 15 major spending categories across FY 2014/2015 to FY 2018/2019 (Fig. 2) (ChiSquared $=26.4, \mathrm{df}=56, p=1.00)$. In FY 2018/2019, an estimated $\$ 61.0 \mathrm{M}(80.7 \%)$ of NOSM's total spending occurred in the service region, which included $\$ 11.2 \mathrm{M}$ in support of programs, $\$ 40.8 \mathrm{M}$ for salary of staff and clinical teachers, and $\$ 9.0 \mathrm{M}$ for residents' salary. All other learners were estimated to spend an additional $\$ 3.6 \mathrm{M}$, bringing the estimated grand total spending in the region to $\$ 64.6 \mathrm{M}$ in 2019 .

The total economic impact in the service region was estimated to be $\$ 107 \mathrm{M}$ in 2019 (Fig. 3). This estimate assumed that some of the money that leaked out of one community in Northern Ontario would be spent in another community in Northern Ontario before leaving the region. In the two largest economic zones of Thunder Bay CMA and Greater Sudbury CMA, the economic impact was \$38 M (35.0\% of total) and \$35.7 M (33.3\% of total), respectively. The impact of spending in communities outside of these urban areas summed to $\$ 19.7$ M (18.4\% of the total impact). Intra-regional spending contributed an additional \$14.2 M (13.3\%). Per capita impact generally followed the same pattern, though the Sioux Lookout CSD and the Temiskaming Shores CSD+ had a per capita impact that was surpassed only by Greater Sudbury and Thunder Bay (Table 1). 


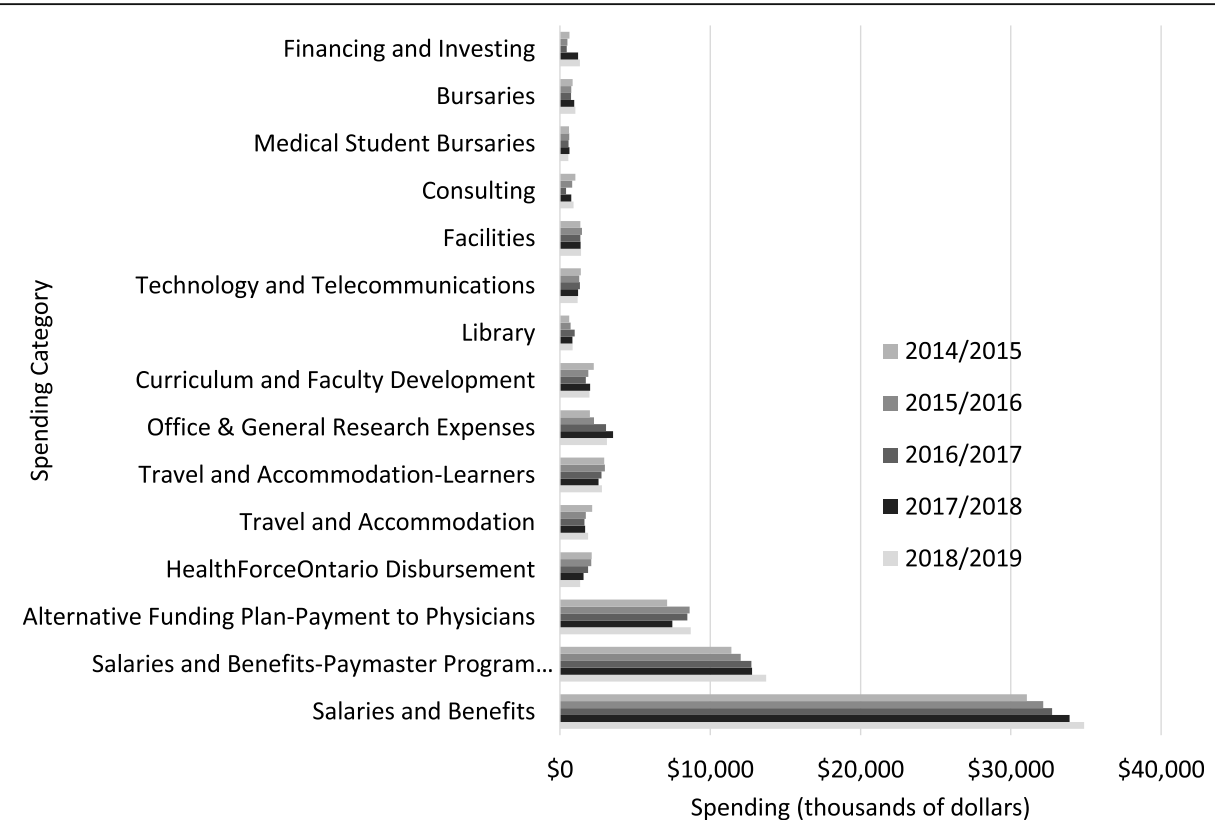

Fig. 2 Spending in all geographic zones in fiscal years 2014/2015-2018/2019 by the Northern Ontario School of Medicine and related programs. a Includes Northern Ontario School of Medicine (NOSM) educational programs and research activities, the Paymaster program for medical resident salaries, and Alternate Funding Plan for clinical teaching reimbursement. Spending by other learners was not included. ${ }^{b}$ The amounts, counted in the hundreds of thousands of dollars, were not statistically significantly different among 15 major spending categories across all fiscal years (Chi-Squared $=26.4, \mathrm{df}=56, p=1.00$ )

Spending in 16 First Nations (Indigenous) communities averaged $\$ 8900$ with an estimated impact of $\$ 10,400$ per community. This represented a per capita impact of $\$ 10$ in communities that ranged in size from approximately 140 to approximately 2500 people (average of 1012 people).

There were 404 full time equivalent (FTE) positions in 2019 in Northern Ontario with an employment impact of 702 FTEs in the region (Table 1). The pattern of employment impact in the region mirrored that of income impact.

In November 2018, there were 226 family physicians and 30 other medical or surgical specialists who had trained at NOSM and were practising in the region (Table 1). The economic impact of these physicians in the region was estimated to total $\$ 87.7 \mathrm{M}$.

\section{Discussion}

For every dollar spent by NOSM, including monies spent in support of clinical duties by residents, reimbursement for teaching duties by physicians, and spending by learners, an estimated $\$ 0.66$ was generated in additional economic activity in 2019 in NOSM's service region of Northern Ontario. Although 68\% of economic impact occurred in the two largest population centres, other cities and towns in the region shared $18 \%$ of the economic impact, while the intra-regional economic impact was estimated at $13 \%$. The economic impact in Northern Ontario increased by $60 \%$ over eleven years, from $\$ 67 \mathrm{M}$ in 2008 [2] to $\$ 107 \mathrm{M}$ in 2019, which reflected NOSM's much expanded suite of education programs, research activities, additional learners, and other funding that flowed through NOSM. If the same multipliers are used in both studies, then NOSM's economic impact increased by $94 \%$ to $\$ 130 \mathrm{M}$.

There are only a few published studies that have examined the economic impact of distributed medical education programs on individual communities. In 2010, the economic impact of Montana's part of the Washington, Wyoming, Alaska, Montana and Idaho (WWAMI) medical education program in clinical teaching sites located away from the main campus in Bozeman was estimated to be $\$ 7.2 \mathrm{M}$ USD [3], equivalent to $\$ 8.7 \mathrm{M} C D N$ in 2019. In comparison, the total annual economic impact of NOSM in 2019 was $\$ 34 \mathrm{M}$ outside of the two largest population centres: four times that of Montana's WWAMI program.

A local comparison comes from an economic impact study of the academic health sciences centre in Greater Sudbury (Health Sciences North-HSN) [35]. HSN had an economic impact of $\$ 310 \mathrm{M}$ in the city and $\$ 2.6 \mathrm{M}$ in nearby communities in FY 2010/2011-equivalent to $\$ 345 \mathrm{M}$ and $\$ 2.9 \mathrm{M}$ in FY 2018/2019. Although HSN revenues and expenditures were 8 -times higher than that 


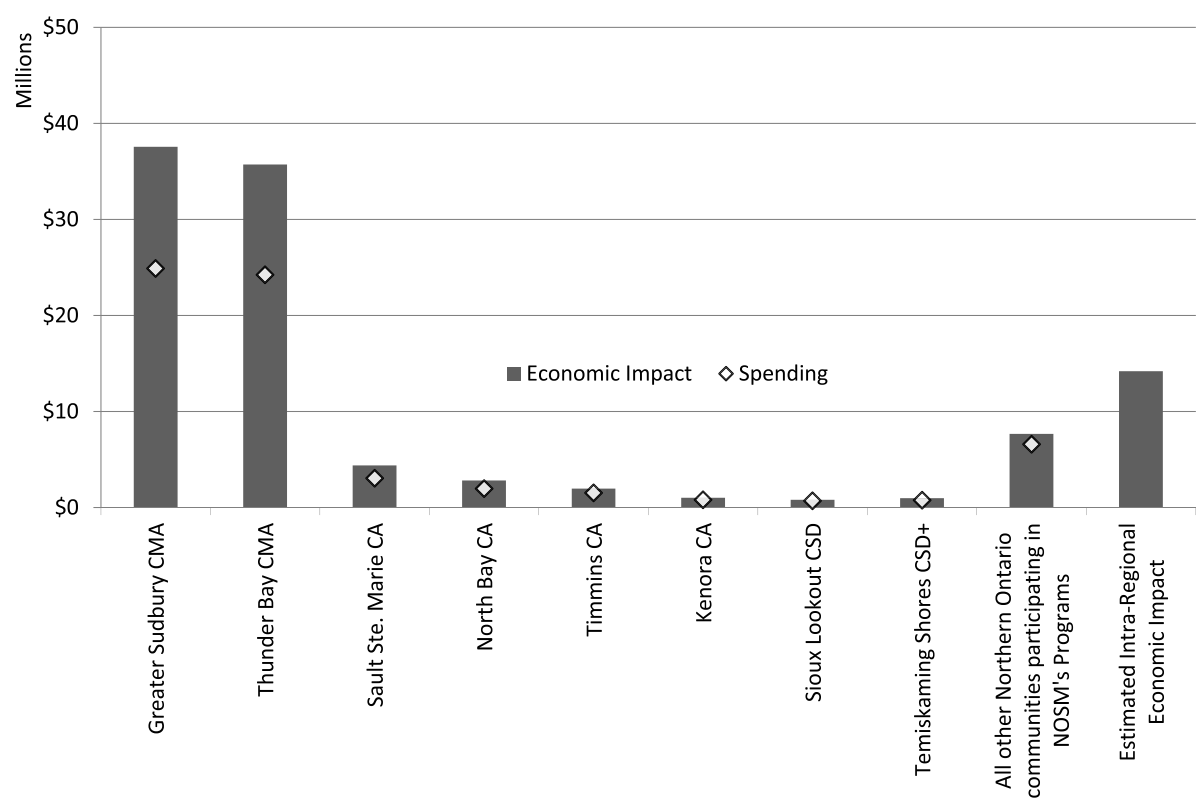

Fig. 3 Total spending $(\diamond)$ and economic impact (bars) (millions of Canadian dollars) in the service region of the Northern Ontario School of Medicine (NOSM) for fiscal year 2018/2019. ${ }^{a}$ Includes the Northern Ontario School of Medicine (NOSM) educational programs and research activities, the Paymaster program for medical resident salaries, academic Alternate Funding Plan for clinical teaching reimbursement, and spending by other learners. ${ }^{b}$ CMA: Census Metropolitan Area. ${ }^{c}$ CA: Census Agglomeration. ${ }^{d}$ CSD: Census Subdivision. ${ }^{e}$ CSD+: Census Subdivision, plus all areas that comprised the former CA

of NOSM, HSN's impact outside of Sudbury was onetwelfth of NOSM's impact outside of Sudbury or Thunder Bay. Much of this difference can be explained by a difference in mandates and organizational structure. For instance, HSN serves as the hospital for Greater Sudbury as well as a tertiary and quaternary care referral centre for northeast Ontario, with each community having its own independent hospital. In comparison, NOSM has central campuses in Greater Sudbury and Thunder Bay, with teaching sites in over 90 communities across northeast and northwest Ontario. Notwithstanding the differences in organizational mandates, NOSM's 12-fold higher impact outside of the major urban areas demonstrated a distributed impact.

However, the economic impact relative to the gross domestic product (GDP) of the region was small. The best available information suggested that the economic impact of $\$ 107$ million represented $0.3 \%$ of the region's GDP [43, 44]. It is also important to note that spending and economic impact disproportionately accrued to the larger population centres of Greater Sudbury and Thunder Bay as evidence by the higher per capita impact values. More could be done to achieve an equitable distribution while recognizing differences in infrastructure, industry diversity, population size, proximity to larger centres, propensity to spend locally, and other salient economic characteristics as well as pertinent programmatic opportunities and challenges.
Regardless of the proportion of GDP and per capita impact, spending by DME programs in participating communities and the impact associated with respending constitutes an investment in economically deprived regions and may help improve employment, income, education, and other social determinants of health $[8,45,46]$. In many communities, this spending represents new money. Findings from an earlier study [2, 47], from a similar study conducted on a DME program in Québec [48], and a study that specifically examined impact on recruitment in DME communities [49] have demonstrated additional social and economic benefits in participating communities. These studies have also shown an increase in civic pride, reputation, networking opportunities, recruitment of healthcare professionals, attractiveness to new businesses, and other benefits in the community. There was more than dollars at work, though new dollars helped.

\section{Limitations}

There are practical and theoretical limits to local economic impact analyses [30-34]. Nonetheless, this approach is considered reasonable for short-term estimates in small, simple economies [31] such as Northern Ontario and it is commonly used to estimate the economic impact of universities, teaching hospitals, and medical schools $[1,3,30]$. 


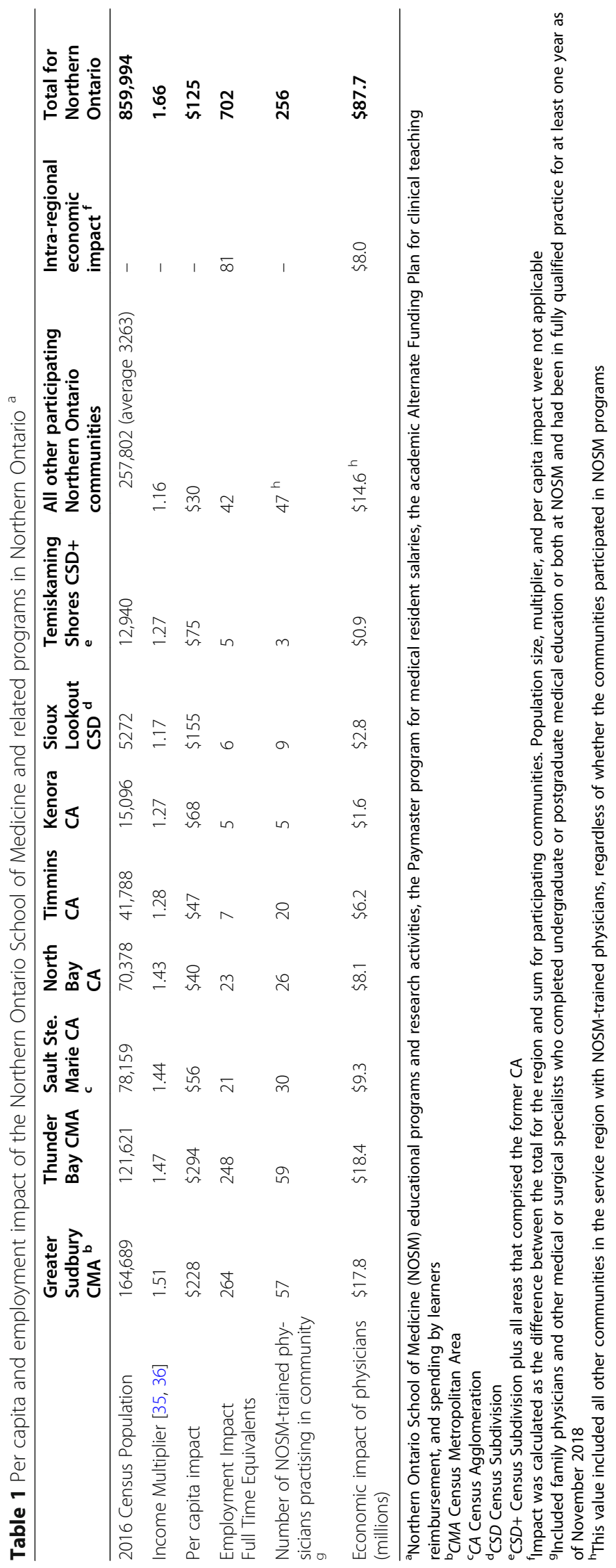


The counterfactual was the absence of any of the programs and activities associated with NOSM. This was used because of the difficulty in obtaining program spending information before NOSM, and because NOSM subsumed all previous programs, added more programs, and increased the number of learners, staff, and teachers. Consequently the net economic impact of NOSM may be lower than estimated by our model. However, our model did not measure all benefits (described later in the discussion), which may justify the higher estimate.

In the absence of detailed spending data for 2019, the model used a ratio to adjust spending in 2015 to that in 2019. An examination of spending in broad categories showed no significant differences across five fiscal years and so the use of this ratio seemed reasonable.

Income multipliers were developed prior to 2012 for communities in Ontario and do not differentiate among spending type. Community population size is the sole independent variable, though the formula accounted for industry diversity and propensity to spend locally [36]. Nonetheless, these multipliers were in the range estimated in 2019 for the health care and social assistance sector in Northern Ontario [40]. Increasing the income multiplier by $4 \%$ to estimate employment impact seemed reasonable given a similar difference between income and employment multipliers in the aforementioned publication [40].

\section{Unmeasured benefits}

Our approach did not consider all economic activity linked to NOSM. For instance, the model excluded some spending by graduate research students, visitor spending, and construction costs-all three of which were minimal. With a focus on NOSM programs and activities, the model included spending of funds that reimbursed clinicians for teaching duties, but not other types of clinician spending. This additional economic impact can be large $[49,50]$. For example, a very preliminary estimate suggested that NOSM-trained physicians who located their practice in the region had an economic impact of $\$ 88 \mathrm{M}$.

Also out-of-scope was any change in the economic burden associated with improved health status or social impact $[47,51]$ attributable to NOSM. We expect that these benefits have accrued, but we do not have evidence to support this claim. On the other side of the equation, the model excluded the cost of municipal services required by NOSM employees, learners, or clinical teachers. However, these demand costs may be negligible or negative, given that the population is stable or declining in most Northern Ontario communities [12].

Our study did not assess how the economic impact of NOSM-related spending compared to other existing or potential provincial healthcare initiatives. The timing and focus of new government project and program expenditures is complex and largely opaque, but there is no reason to think that NOSM displaced other public spending for healthcare or development in Northern Ontario. On the contrary, it is likely that the presence of NOSM has attracted other developments in academic and health sectors including the health research institutes in Thunder Bay and Sudbury. Nor is there any reason to think that NOSM displaced monies that were otherwise going to frontline care in the region. It is possible that NOSM reduced the need to transport some patients to large centres for primary or ambulatory care, but this is probably a small effect. Future study is required to account for all costs and benefits to assess the relative impact on economic activity.

\section{Conclusions}

Our economic impact study demonstrated that NOSM's DME programs and associated activities, spending by staff, clinical teachers and learners, and research activities contributed to the Northern Ontario economy in a way that extended beyond the production of health care professionals. In Northern Ontario, the economic impact on participating communities was at least $60 \%$ greater than the original government investment. This expenditure in a low resource region provided an economic stimulus and, along with NOSM graduates who set up practice in the region, may help improve the social determinants of health and the health of the population. DME is also DEI-distributed economic impact.

\section{Abbreviations \\ CA: Census agglomeration (www12.statcan.gc.ca/census-recensement/2016/ ref/dict/geo009-eng.cfm); CDN: Canadian; CMA: Census metropolitan area (www12.statcan.gc.ca/census-recensement/2016/ref/dict/geo009-eng.cfm); CRaNHR: Centre for Rural and Northern Health Research-Laurentian (www. cranhr.ca); CSD: Census subdivision (www12.statcan.gc.ca/census- recensement/2016/ref/dict/geo012-eng.cfm); DEl: Distributed economic impact; DME: Distributed medical education; FP: Family (medicine) physicians/practitioners; FTE: Full time equivalent; FY: Fiscal year; HSN: Health Sciences North (www.hsnsudbury.ca); NOSM: Northern Ontario School of Medicine (www.nosm.ca)}

\section{Supplementary Information}

The online version contains supplementary material available at https://doi. org/10.1186/s13561-021-00317-z.

Additional file 1. Explanation of Spending Envelopes.

Additional file 2. Educational Programs before and after the inception of the Northern Ontario School of Medicine.

\section{Acknowledgments}

The authors thank Dan Burrell, Gayle Adams-Carpino, Jennifer Fawcett, John Friesen, Ray Hunt, Joe Lipinski, Mathieu Litalien, Denise Raftis, Rachel Schaaf, and John Shea, NOSM, and Kaitlin Bynoski, University of Waterloo, for providing aggregated data on programs, including spending and details of other economic impacts on communities. This study built upon an earlier economic impact model developed in 2008 by John C. Hogenbirk and David R. 
Robinson as part of a broader socio-economic impact study funded by the Ontario Ministry of Health and Long-Term Care (MOHLTC). The authors thank the reviewers for their comments on the manuscript. The views expressed in this paper are those of the authors and do not necessarily reflect that of the NOSM nor the MOHLTC.

\section{Authors' contributions}

All authors (JCH, DRR, RPS) made substantial contributions to the conception or design of the work, and to the interpretation of data for the work. JCH acquired the data and conducted the modelling in consultation with DRR. JCH drafted the manuscript, while DRR and RPS critically revised the text for important intellectual content. All authors provided final approval of the submitted version and have agreed to be "accountable for all aspects of the work in ensuring that questions related to the accuracy or integrity of any part of the work are appropriately investigated and resolved" (http://www. icmje.org/recommendations/browse/roles-and-responsibilities/defining-therole-of-authors-and-contributors.html).

\section{Authors' information}

$\mathrm{JCH}, \mathrm{MSC}$, is Senior Research Associate and Associate Director with the Centre for Rural and Northern Health Research, Laurentian University, Sudbury, Ontario, Canada. JCH conducts national and international research on medical schools' admissions policies, socio-economic impact, discipline choice, and graduate practice location as well as on health service access and utilization in rural regions and other underserved areas.

DRR, PhD, is an Associate Professor with the School of Northern and Community Studies, Laurentian University, Sudbury, Ontario, Canada. DRR is an economist and a leading expert on Northern Ontario economic development.

RPS, AM, MBBS, MCISC, is Professor of Rural Health and Founding Dean Emeritus of the Northern Ontario School of Medicine (NOSM), Laurentian University, Sudbury, and Lakehead University, Thunder Bay, Ontario, Canada. RPS undertakes research into aspects of rural health with studies of: the health needs of small rural communities; sustainable models of health care in remote rural communities; rural health workforce, particularly rural family physicians; rural medical and health professional education and training outcomes and impact; and recruitment and retention of remote rural health workers.

\section{Funding}

Funding for the study was provided to the Centre for Rural and Northern Health Research (CRaNHR) by the Northern Ontario School of Medicine (NOSM) with monies approved by the Ontario Ministry of Health and LongTerm Care (MOHLTC).

\section{Availability of data and materials}

Aggregated data are available from the corresponding author upon reasonable request.

\section{Declarations}

\section{Ethics approval and consent to participate}

Researchers at the Centre for Rural and Northern Health Research (Laurentian University) obtained anonymous program data through a data sharing agreement with the Northern Ontario School of Medicine and the study was exempt from ethical review.

\section{Consent for publication}

Not applicable.

\section{Competing interests}

$\mathrm{JCH}$ works part-time for the Northern Ontario School of Medicine as a Research Tutor in the Postgraduate Family Medicine Program. RPS was Dean and CEO of NOSM at the time of the study.

\section{Author details}

'Centre for Rural and Northern Health Research, Laurentian University, 935 Ramsey Lake Road, Greater Sudbury, Ontario P3E 2C6, Canada. ${ }^{2}$ School of Northern and Community Studies, Laurentian University, 935 Ramsey Lake Road, Greater Sudbury, Ontario P3E 2C6, Canada. ${ }^{3}$ Professor of Rural Health, and Founding Dean Emeritus, Northern Ontario School of Medicine, 935 Ramsey Lake Road, Greater Sudbury, Ontario P3E 2C6, Canada.

\section{Received: 22 July 2020 Accepted: 9 May 2021}

Published online: 09 June 2021

\section{References}

1. Association of Faculties of Medicine of Canada. The Economic Impact of Canada's Faculties of Medicine and Health Science Partners. Ottawa: Prepared by Tripp Umbach for The Association of Faculties of Medicine of Canada; 2014. http://www.afmc.ca/pdf/Economic Impact_Study_Report FINAL_EN.pdf. Accessed 15 Jun 2020

2. Hogenbirk JC, Robinson DR, Hill ME, Pong RW, Minore B, Adams K, et al. The economic contribution of the Northern Ontario School of Medicine to communities participating in distributed medical education. Can J Rural Med. 2015;20(1):25-32

3. Tripp Umbach. Montana's medical school: the economic and social impact of the Montana WWAMI program. Bozeman: Montana State University; 2011. https://www.montana.edu/wwami/documents/Economic-Impact-ofWWAMI.pdf. Accessed 15 Jun 2020.

4. Davies SM, Bennett A. Understanding the economic and social economic and social effects of academic clinical partnerships. Acad Med. 2008:83(6): 535-40. https://doi.org/10.1097/ACM.0b013e3181723033.

5. Clancy GP. Linking health equity with economic development: insights from my year as chairman of the Board of the Chamber of commerce. Acad Med. 2012:87(12):1665-7. https://doi.org/10.1097/ACM.0b013e318272113f.

6. Park B, Frank B, Likumahuwa-Ackman S, Brodt E, Gibbs BK, Hofkamp H, et al. Health equity and the tripartite mission: moving from academic health centers to academic-community health systems. Acad Med. 2019;94(9): 1276-82. https://doi.org/10.1097/ACM.0000000000002833.

7. Halseth G, Markey S, Ryser L, editors. Service provision and rural sustainability: infrastructure and innovation. London: Routledge; 2018. https://doi.org/10.4324/9781138483736.

8. Marmot MS, Friel S, Bell R, Houweling TA, Taylor S. Closing the gap in a generation: health equity through action on the social determinants of health. Lancet. 2008;372(9650):1661-9. https://doi.org/10.1016/S0140-673 6(08)61690-6.

9. Farmer J, Prior M, Taylor J. A theory of how rural health services contribute to community sustainability. Soc Sci Med. 2012;75(10):1903-11. https://doi. org/10.1016/j.socscimed.2012.06.035.

10. Blane DN. Medical education in (and for) areas of socio-economic deprivation in the UK. Educ Prim Care. 2018;29(5):255-8. https://doi.org/10.1 080/14739879.2018.1512056.

11. Andermann A. CLEAR collaboration. Taking action on the social determinants of health in clinical practice: a framework for health professionals. Can Med Assoc J. 2016;188(17-18):E474-83. https://doi.org/1 $0.1503 /$ cmaj.160177.

12. Statistics Canada. Census Profile, 2016. Census Release date: February 8, 2017, catalogue no. 98-316-X2016001, http://www12.statcan.gc.ca/ censusrecensement/2016/dp-pd/prof/index.cfm?Lang=E\&TABID=1. Accessed 24 Apr 2017.

13. Conteh C. Economic Zones of Northern Ontario: City-Regions and Industrial Corridors. Research report no. 18. Thunder Bay: Northern Policy Institute; 2017. https://www.northernpolicy.ca/upload/documents/publications/ reports-new/conteh economic-zones-en.pdf. Accessed 15 Jun 2020.

14. Canadian Institute for Health Information. How Healthy are Rural Canadians? An assessment of their health status and health determinants. Ottawa; 2006. https://secure.cihi.ca/free_products/acknowledgements_rural_canadians_2 006 report e.pdf. Accessed 15 Jun 2020

15. Statistics Canada. Northeast [economic region], Ontario and Ontario [Province] (table). In: Census Profile. Ottawa: 2016 Census. Statistics Canada Catalogue no. 98-316-X2016001; 2017a. Released 29 Nov 2017. https:// www12.statcan.gc.ca/census-recensement/2016/dp-pd/prof/details/page. $\mathrm{cfm} ? \mathrm{~B} 1=$ All\&Code $1=3590 \&$ Code $2=35 \&$ Data $=$ Count $\&$ Geo $1=$ ER\&Geo2=PR\&La $\mathrm{ng}=\mathrm{E} \&$ SearchPR $=01 \&$ SearchText=Northeast\&SearchType=Begins\&TABID $=1$. Accessed 19 Jun 2020

16. Statistics Canada. 2017b. Northwest [economic region], Ontario and Ontario [Province] (table) Census Profile 2016 Census Statistics Canada Catalogue no 98-316-X2016001 Ottawa Released 29 Nov 2017. https://www12.statcan.gc. $\mathrm{ca} /$ census-recensement/2016/dp-pd/prof/details/page.cfm?B1=All\&Code1= 3595\&Code2=35\&Data $=$ Count\&Geo1 $=$ ER\&Geo2 $=$ PR\&Lang $=E \& S e a r c h P R=01$ 
\&SearchText=Northwest\&SearchType=Begins\&TABID=1. Accessed 19 Jun 2019.

17. Ontario Ministry of Francophone Affairs. 2019. Profile of the Francophone population in Ontario - 2016. https:/www.ontario.ca/page/profile-fra ncophone-population-ontario-2016. Accessed 19 Jun 2020.

18. MacMillian HL, Walsh CA, Jamieson E, et al. The health of Ontario First Nations people. Can J Public Health. 2003;94(3):168-72. https://doi.org/10.1 007/BF03405059. Accessed 19 Jun 2019.

19. Bouchard L, Batal M, Imbeault P, et al. La santé des Francophones de I'Ontario : Un portrait régional tiré des Enquêtes sur la santé dans les collectivités canadiennes. Ottawa: Réseau de recherche appliquée sur la santé des Francophones de l'Ontario; 2012. http://www.rrasfo.ca/images/ docs/publications/2012/rapport_escc_ontario-final.pdf. Accessed 19 Jun 2019.

20. Glazier RH, Gozdyra P, Yeritsyan N. Geographic Access to Primary Care and Hospital Services for Rural and Northern Communities: Report to the Ontario Ministry of Health and Long-Term Care. Toronto: Institute for Clinical Evaluative Sciences (ICES); 2011. https://www.ices.on.ca/ /media/ Files/Atlases-Reports/2011/Geographic-access-to-primary-care-for-northern-a nd-rural-communities/Full-report.ashx. Accessed 15 Jun 2020.

21. Green ME, Gozdyra P, Frymire E, Glazier RH. Geographic Variation in the Supply and Distribution of Comprehensive Primary Care Physicians in Ontario, 2014/15. Toronto: Institute for Clinical Evaluative Sciences (ICES); 2017. https://www.ices.on.ca/ /media/Files/Atlases-Reports/2017/Geogra phic-variation-in-physician-supply/Report.ashx. Accessed 15 Jun 2020.

22. Tepper JD, Schultz SE, Rothwell DM, Chan BTB. Physician Services in Rural and Northern Ontario. ICES investigative report. Toronto: Institute for Clinical Evaluative Sciences; 2005. https://www.ices.on.ca/Publications/Atlases-andReports/2006/Physician-services-in-rural-and-northern-Ontario. Accessed 15 Jun 2019.

23. Strasser R, Lanphear JH, McCready WG, et al. Canada's new medical school: the Northern Ontario School of Medicine - social accountability through distributed community engaged learning. Acad Med. 2009;84(10):1459-6. https://doi.org/10.1097/ACM.0b013e3181b6c5d7.

24. Strasser R, Hogenbirk JC, Minore B, Marsh DC, Berry S, Mccready WG, et al. Transforming health professional education through social accountability: Canada's Northern Ontario School of Medicine. Med Teach. 2013;35(6):4906. https://doi.org/10.3109/0142159X.2013.774334.

25. Grobler L, Marais BJ, Mabunda S. Interventions for increasing the proportion of health professionals practising in rural and other underserved areas. Cochrane Database Syst Rev. 2015;6. https://doi.org/10.1002/14651858. CD005314.pub3.

26. Seifer SD, Vranizan K, Grumbach K. Graduate medical education and physician practice location. Implications for physician workforce policy. J Am Med Assoc. 1995;274(9):685-91. https://doi.org/10.1001/jama.1995.0353 0090017015

27. Heng D, Pong RW, Chan BTB, et al. Graduates of northern Ontario family medicine residency programs practise where they train. Can J Rural Med. 2007;12:146-52

28. Woolley T, Hogenbirk JC, Strasser R. Retaining graduates of nonmetropolitan medical schools for practice in the local area: The importance of locally based postgraduate training pathways in Australia and Canada. Rural and Remote Health. 2020;20:5835. https://doi.org/10.22605/RRH5835.

29. Ontario, Province of. Health and Education at Centre of Plan for New Generation of Economic Growth. 2004. https://news.ontario.ca/opo/en/2 004/03/mcguinty-government-tackling-doctor-shortage.html. Accessed 29 Jun 2020.

30. Caffrey J, Isaacs HH. Estimating the impact of a college or university on the local Economy. Washington, DC: American Council on Education; 1971.

31. Davis HC. Regional economic impact analysis and project evaluation. Vancouver, BC: UBC Press; 1990.

32. Ryan GJ, Malgieri P. Economic Impact Studies in Community Colleges: The Short Cut Method. 2nd ed. Washington, DC: National Council for Resource Development; 1992. Report No 48

33. Watson P, Wilson J, Thilmany D, Winter S. Determining economic contributions and impacts: what is the difference and why do we care? J Regional Analysis Policy. 2007;37:140-6.

34. Siegfried J, Sanderson AR, McHenry P. The economic impact of colleges and if universities. Econ Educ Rev. 2007;26(5):546-58. https://doi.org/10.1016/j. econedurev.2006.07.010.
35. Hogenbirk JC, Zitikyte D, Kaymak D, et al. The Socio-Economic Contribution of Health Sciences North / Horizon Santé-Nord to Northeastern Ontario. Sudbury, Ontario: Centre for Rural and Northern Health Research; 2014. http://documents.cranhr.ca/pdf/Report_HSN_Socio_Economic_Impact_ Study_2014_03_31_FINAL.pdf. Accessed 3 Jul 2019.

36. Lasota M, Gormanns N, McCracken M. Health sciences north (HSN) economic impact: application of multipliers in the local impact model. Ottawa: Informetrica Limited; 2012.

37. Statistics Canada. Dictionary, Census of Population, 2016. Release date: November 16, 2016 Updated on: February 8, 2017, http://www12.statcan.gc. ca/census-recensement/2016/ref/dict/index-eng.cfm, Catalogue no. 98-301X. Accessed 15 Jun 2020.

38. Northern Ontario School of Medicine (NOSM) Financial Statements http:// www.nosm.ca/about_us/general.aspx?id=17503. Accessed 15 Jun 2020.

39. Burrell, D. Personal Communications. 2017. 11 Dec 2017.

40. Moazzami B. Income and Employment Multipliers for 20 Industries in 11 Census Divisions in Northern Ontario. Thunder Bay: Northern Policy Institute; 2019. https://www.northernpolicy.ca/income-multipliers. Accessed $17 \mathrm{Jul}$ 2020.

41. Schultz SE, Glazier R, Graves E, et al. Payments to Ontario physicians from Ministry of Health and Long-Term Care sources: Update 2005/06 to 2017/18. Toronto: Institute for Clinical Evaluative Sciences (ICES); 2019. https://www. ices.on.ca/ /media/Files/AHRQ/AHRQ-Reports/Physician-CompensationUpdate-2005 06-to-2017 18.ashx. Accessed 19 Jul 2020.

42. Conference Board of Canada. Physicians' Offices in Canada: Assessing Their Economic Footprint. Ottawa, Canadian Medical Association; 2017. https:// www.cma.ca/sites/default/files/pdf/health-advocacy/activity/physicians_\%2 Ooffices_canada_economic_footprint_2017_e.pdf. Accessed 19 Apr 2021.

43. Moazzami B. Northeastern Ontario's Economy. Northern Ontario economist (website); 2015a. http://www.northernontarioeconomist.com/upload/ documents/northeastern-ontario-report.pdf. Accessed 20 Mar 2021.

44. Moazzami B. Northwestern Ontario's Economy. Northern Ontario economist (website); 2015b. http://www.northernontarioeconomist.com/upload/ documents/northwestern-ontario-report.pdf. Accessed 20 Mar 2021.

45. Beraldo S, Montolio D, Turati G. Healthy, educated and wealthy: a primer on the impact of public and private welfare expenditures on economic growth. J Socio-Econ. 2009;38(6):946-56. https://doi.org/10.1016/.socec.2009.06.013.

46. McCullough JM. Local health and social services expenditures: an empirical typology of local government spending. Prev Med. 2017;105:66-72. https:// doi.org/10.1016/j.ypmed.2017.08.018.

47. Hogenbirk JC, Hill ME, Robinson DR, et al. Exploring the socio-economic impact of Northern Ontario School of Medicine: final report. Sudbury: Submitted to the Northern Ontario School of Medicine; 2009. http:// documents.cranhr.ca/pdf/FINAL_Report_(NOSM_Socioeconomic_Impact_ Study-2009-11).pdf. Accessed 15 June 2020.

48. Bergeron G. Le développement territorial durable aux échelles infranationales: Le cas du programme de formation médicale à Saguenay. Revue Organisations Territoires. 2015;24(1):7-18. https://doi.org/10.1522/ revueot.v24i1.110

49. Mian OX, Hogenbirk JC, Strasser PR, Warry W. How underserviced rural communities approach physician recruitment: changes following the opening of a socially accountable medical school in northern Ontario, Canada. Can J Rural Med. 2017;22(4):139-47.

50. Rotarius T, Liberman A, Trujillo A. Economic contributions of physicians-the financial impact on their community. Health Care Manager. 2008;27(4):31723. https://doi.org/10.1097/HCM.0b013e31818c8088.

51. Toomey P, Lovato CY, Hanlon N, Poole G, Bates J. Impact of a regional distributed medical education program on an underserved community: perceptions of community leaders. Acad Med. 2013;88:1-8. https://doi.org/1 0.1097/ACM.0b013e318290f9c7.

\section{Publisher's Note}

Springer Nature remains neutral with regard to jurisdictional claims in published maps and institutional affiliations. 